\title{
The Effect of Audit Committee Characteristics on Audit Quality: The Moderating Role of Internal Audit Function
}

\author{
Josephine Kuan Pei See ${ }^{1}$, Anwar Allah Pitchay ${ }^{2}$, Yuvaraj Ganesan ${ }^{*}$, Hasnah Haron ${ }^{4}$, Ratih Hendayani ${ }^{5}$ \\ ${ }^{1}$ AGCO GSI Malaysia Sdn. Bhd., Penang, Malaysia. \\ ${ }^{2}$ School of Management, Universiti Sains Malaysia, Penang, Malaysia. \\ ${ }^{3}$ Graduate School of Business, Universiti Sains Malaysia (USM), Penang, Malaysia. \\ ${ }^{4}$ Accounting Research Institute, Universiti Teknologi Mara, Selangor, Malaysia. \\ ${ }^{5}$ School of Economics and Business, Telkom University, Bandung, Indonesia.
}

\begin{abstract}
The purposes of study are to examine the effect of audit committee characteristics namely gender, frequency of meetings, independence member in audit committee and audit committee size on audit quality and the moderating role of internal audit function in the relationship between audit committee characteristics and audit quality. The objective is to contribute to the new evidence on the role of audit committee characteristics plays towards the audit quality with internal audit function as moderator. This research applied a quantitative approach and secondary data as the main source of information for analysis. The stratified random sampling techniques are being used in this study. Further, the structural equation modelling (SEM) approach via SmartPLS was utilized to achieve the research purpose by evaluating the data collected from 250 public listed companies in Malaysia. The results reveal that only three of the audit committee characteristics, namely presence of female members in the audit committee, frequency of meetings and independence of directors, are positively influencing the audit quality for listed companies in Malaysia. Surprisingly, this study also found that internal audit function did not play moderating effect in the relationship between audit committee characteristics and audit quality. The findings will facilitate researchers and scholars in enhance the understanding of audit committee characteristics particularly the gender, frequency of $\mathrm{AC}$ meetings and independence members in the audit committee played in improving overall audit quality. The companies' stakeholders like professional accountancy body and governments may use the outcomes from this research study to improve existing rules and governance regulations and code of conducts of its members to improve the quality of their works. This study contributes to the relatively new discussion on the effect of audit committee characteristics on audit quality by adding internal audit function as moderator in Malaysia. Outcome from this study may assist the companies' stakeholders like professional accountancy body and governments in determining improved methods to enhance audit committee characteristics in improving audit quality.
\end{abstract}

ARTICLE HISTORY

Received: 29-05-2020

Accepted: $27-07-2020$

\section{KEYWORDS}

Audit Committee

Characteristics, Internal Audit

Function, Audit Quality,

Agency Theory, Gender, AC

Size, Independent Directors

\section{INTRODUCTION}

Auditors assume a very important role in producing high-quality financial statements for the users for managing the affairs of the company by assessing the financial performance and position in order to make important business decisions. High quality on financial reporting and audit are supporting the global financial stability. Unfortunately, in reality, the audit quality is not solely being measured against the conformation to the auditing standards. There is no single definition of audit quality but the audit quality consists of, firstly the decipherment ability of auditor on the possibility of significant errors in the financial statements, secondly the possibility of not issuing conditional report by the auditor for financial statements that are containing important errors, thirdly the review of the auditor's ability of reducing biased errors and misstatements and improving the accounting data quality, fourthly the accuracy of information that being used in the auditors' report and lastly the level of auditors' competency and independency in the course of audit and their independency perception by the users of the auditors' report (Salehi, Moradi, \& Paiydarmanesh, 2017). Generally, it is very simple to measure a product quality based on design, performance, durability and effectiveness. However, audit quality measurement could be difficult. Many auditors are making assumption that their audit works are quality as long as the audit works are performance in accordance to the Generally Accepted Auditing Standards (GAAS) and approved accounting standards and meeting minimum legal and professional requirements. In Malaysia, there are several laws outline the requirements for corporate financial reporting.

The external auditors normally perform audit of companies' financials using a set of systematic guidelines so called GAAS to ensure accuracy, consistency and verifiability of auditors' reports. The auditors must express an overall opinion regarding the financial statements. When the auditors are unable to express an overall opinion, the reasons must be stated 
in the auditors' reports. The auditors must also state in the auditors' report in the event where the informative disclosures are not reasonably adequate and misleading the users of the financial statements. The auditors must consider the areas of high assessed risk of material misstatement where involving significant management judgement in the financial statements and significant events or transactions that will materially impact the audit during the accounting period. The auditors are required to communicate the key audit matters in the auditors' reports in order to improve the communication value and audit quality by providing greater transparency for the audit works performed ("International Standard on Auditing (ISA) 701 (NEW), Communicating Key Audit Matters in the Independent Auditor's Report", 2019). The overall audit quality is very important as the users of the financial statements are relying on the auditors' reports as well as other disclosures in the financial statements for decision makings.

The recent failure in the professional auditing responsibilities among "Big Four" firms has destroyed public confidence in audit quality generally. The Securities Commission Malaysia was investigating the conduct of the international auditors KPMG and Deloitte in relation to 1MDB the biggest corruption scandal. Deloitte was fined RM2.2 million for failing to perform its duty and report the irregularities by the Securities Commission Malaysia. This has raised the questions on corporate governance control, compliance and business ethics in Malaysia especially the role of AC in 1MDB case towards the audit quality carried out by international auditors KPMG and Deloitte (Lee, 2019). Following to collapse of the United Kingdom's second largest construction company in the country, Carillion PLC of which the internal auditor Deloitte had failed to identify any terminal failing in risk management and financial controls, the Competition and Markets Authority in the UK has proposed to break up the "Big Four" accountants to increase competition and audit quality by splitting their audit and consulting businesses (Davies, 2019). The main reason for the call of the breakup is due to the existing poor control by the Board of Directors and Audit Committee in ensuring risk management and financial controls and the internal audit function's role is strong enough in these areas. As a result of growing pressure from regulators, PwC has announced plans for a significant transformation of its audit business by splitting in two, i.e. audit practice to focus on external audit and audit-related services and risk assurance practice to focus on internal audits and cybersecurity and technology risk (Sprouse, 2019).

The first Malaysian Code on Corporate Governance (MCCG) was introduced in 2000 by the Securities Commission Malaysia (SC) (SCM, 2017). This Code was marked as significant milestones in corporate governance reformation in Malaysia that will strengthen the role and importance of Audit Committee (AC) towards the audit quality. The Code was implemented a reaction to the Asian Financial Crisis in 1997. The crisis has raised the fear of the economic meltdown globally as a result of financial contagion and this resulted the topic of corporate governance has become spotlight due to lack of transparency and accountability in the financial sector. One of the requirements under the Code that the AC should comprise a minimum number of three directors and majority should be independent non-executive directors and minimum number of one member from the AC must be of financially literate and having sufficient understanding on the operation and management of the company (SCM, 2017).

The definition of independent directors is provided in the Bursa Malaysia Main Market Listing Requirements as a director who is independent of management and those who is not a full time employee, family members of the employee, bankers, legal consultant/lawyer or professional consultant of the company and has no relationship with the company that could directly or indirectly interfere with the exercise of independent judgement and also the ability to act in the best interest of the shareholders, however, there is no clear definition for non-executive directors (Bursa, Updated as at 13/3/2019). An effective AC plays a crucial role to provide independent judgement needed on the functional areas for an organization such as internal auditing, external auditing, financial management, risk management and legal process. The $\mathrm{AC}$ is important to ensure that the well-management of the company and to protect the interest of the stakeholders as general by bringing substantial transparency in the financial reporting systems, risk controls and management as well as sound internal controls that impacting the audit quality (SCM, 2017).

AC characteristics and Internal Audit Function (IAF) have been highlighted by several academic researchers in enhancing the corporate governance and financial reporting of the companies. IAF has significantly contribute to the accountability of Statutory Corporations in Uganda and the AC effectiveness will play the role in significantly contributing to accountability (Bananuka, Nkundabanyanga, Nalukenge, \& Kaawaase, 2018). AC existence and IAF decreases earnings management in Jordan and improves the quality of financial reporting (Alzoubi, 2019). The AC role and responsibilities have the impact to increase audit quality due to its right to assess the suitability objectivity on overall opinion and independence of the external auditor based on written policies and procedures and as well as to reduce or minimize the risk of illegal functions or irregularities due to its independence position on fully informed about significant matters on the organizations' business affairs (SCM, 2017). Therefore, the AC characteristics are important elements in determining audit quality. Unfortunately, there are not many studies currently focusing on the AC characteristics towards the audit quality.

In order AC to perform its roles and responsibilities, a successful IAF is important to support the AC by offering internal audit, strengthen internal control within all important processes and its activities that will have a positive influence towards the quality of financial information. In addition to monitor internal controls, the IAF is to support in identifying and assessing of business risk (Oussii \& Boulila Taktak, 2018). The AC relies on the work of IAF and has the influence 
in improving the internal audit activities, monitoring process of financial reporting and increase the internal audit function efficiency in the company for risk management (Arena \& Azzone, 2009; Krishnan, 2005). In practice, external auditor is using the work carried out by internal audit with the consideration of the quality of internal audit in terms of the objectivity, competency and work performed by the IAF before relying on the work of internal auditors. The external auditors may again additional insights into the company and internal auditors may bring accounting and auditing issues identified during the course of internal audit to the attention of external auditors based on their knowledge and expertise (Leung, 2013). The external auditors will examine the financial records and issue an opinion regarding the financial statements of the company. By using the work and expertise of internal auditors, the audit and reporting quality of external auditors will improve. Hence, IAF is being chosen as a moderator in this study.

This research study makes several contributions. Firstly, is on the enhancing the AC effectiveness by examining and understanding of the AC characteristics and their effect on the audit quality. This will help companies to improve the audit quality and avoid financial reporting problems. Secondly, this research study will add to the literature in relation to the moderating effect from the IAF towards the audit quality improvements. Nowadays, IAF is playing an important role in providing assurance to the management team and the board of directors on the effectiveness of risk management, governance and control processes. Lastly, this research study will contribute to the extant literature by enhancing scholar knowledge in AC characteristics and the relationship with audit quality in Malaysia especially in the context of enhancing the financial statements value and to protect the interest of the stakeholders like shareholders, professional accountancy body, governments, employees etc. and the moderating role of internal audit function on the relationship between AC characteristics and audit quality. One of the examples is the Malaysian Institute of Accountants may use the outcomes from this research study to improve existing rules and regulations and code of conducts of its members to improve the quality of their works. The results of this research study may also use as reference by the SC for future MCCG revisions. The remainder of the article is being organized as per following order: first review of the literature and hypotheses development, second describes the research procedures such as data collection and analysis method, third presents the results from the statistical analyses, fourth discusses the results, fifth explain the theoretical implications and practical value of this study, sixth outlines the limitation of this study and future studies and lastly provides conclusion of the study.

\section{LITERATURE REVIEW}

\section{Prior research on Audit committee}

The Cadbury Report 1992 has a large influential of corporate governance codes being developed worldwide such as Organisation for Economic Co-operation and Development (OECD) and other countries like Sweden, Malaysia etc. The publication of the Cadbury Report in 1992 has provided the encouragement and impetus for companies to establish an AC. The Cadbury Report has stated that the board of directors should establish an AC with the number of non-executive directors of at least three members. There must be written terms of reference to be documented and to state clearly with the authority and duties of the AC to be performed (Committee on the Financial Aspects of Corporate Governance \& Cadbury, 1992). In Malaysia, the composition of the AC must consist not fewer than three members (Bursa, Updated as at 27/1/2015). This requirement is consistent with other international stock exchanges such as New York Stock Exchange (US), NASDAQ (US), Japan Exchange Group (Japan) and London Stock Exchange (UK). AC size is importance as for an AC to be properly functioning in organisation the adequate manpower is required to ensure all matters and issues are being resolved including any of the issues arising from the internal control and financial reporting (SCM, 2017). Prior research into the effects of the ACs on the audit quality has returned mixed results (Akhtaruddin \& Haron, 2010; AlOkaily \& Naueihed, 2019; Martinov-Bennie, Soh, \& Tweedie, 2015; Safari, 2017).

The AC's role has evolved beyond the requirement of the new regulation and AC is taking more active role in the area of corporate government and risk management (Martinov-Bennie et al., 2015). There are few prior literature on ACs stated that the AC effectiveness is much depending on its characteristics (Akhtaruddin \& Haron, 2010; Al-Okaily \& Naueihed, 2019; Safari, 2017). The more independent directors on the audit committee will increase levels of disclosure and lead to the reduction of information asymmetry between the management team and the shareholders (Akhtaruddin \& Haron, 2010). Larger boards that consist of more business experts and having more hands to work are viewed to have more effective monitoring. As a result, they are in the position of favour corporate disclosure and will end up enhance the quality of the audit (Al-sartawi, Hamdan, Mushtaha, \& Ijela, 2013; Alfraih, 2016). A larger AC is more eager to allocate resources and authority to carry out responsibilities more effectively according to this theory (Allegrini \& Greco, 2011). The deliberate boards and AC structuring is an effective approach for enhancing financial reporting quality and lower potential earnings management activities (Safari, 2017). AC characteristics of size, expertise and frequency of meeting are positively related to non-family firm performance and the $\mathrm{AC}$ effectiveness in enhancing financial performance is depending on the firms' ownership structure (Al-Okaily \& Naueihed, 2019).

\section{Audit Quality}

Audit quality is one of the complete subjects of which there is no definition or analysis of it that has achieved recognition in the universal level. Audit quality is the results of the external audit process whereby the auditors are forming their professional opinion on the audited financial statements based on quality of audit work carried out by the external auditors. The perspectives of audit quality are varying among the stakeholders (IAASB, 2014). If is considering audit 
quality from the perspective of maximizing the amount of audit evidence collected, it would suggest that the audit quality is higher with more resources (both in quantitative and qualitative terms) allocated to the particular audit. On the other hand, if the audit fee and minimizing disruption to the operations as a result of audit activities are a concern to the management, the resources allocation to the audit must be minimized. In balancing between effective and efficient audit in the term of timely performance and for a reasonable fee, ACs in many countries have the responsibility for audit quality consideration, appointment of auditor and approval of audit fee (IAASB, 2014). In the agency theory, the external auditors play a monitoring role that will help to alleviate the agency problems between the board of directors, management team and the shareholders of the organization.

Financial statements preparer and users of the financial statements are part of the audit quality attribute (Carcello, Hermanson, \& McGrath, 1992). The quality of the audit has direct effect on professional scepticism such as experience, commitment, independent, competence and ethics (Kusumawati \& Syamsuddin, 2018). Meanwhile, Salehi et al. (2017) had mentioned that if looking from the auditors' point of view, factors affecting audit quality will directly impact the auditors' ability in detecting material misstatements that presents in the financial report. Engaging with large audit firm and specialized audit will result in higher audit quality delivery (Salehi et al., 2017). The presence of Big Four auditor together with an effective AC will increase the audit quality on corporate voluntary disclosure (Agyei-Mensah, 2019). Companies with lower audit fees have showing a stronger relationship exists between the ability of the management team and internal control quality (Salehi, Tahervafaei, \& Tarighi, 2018). Companies with female Chief Executive Officers (CEOs) are highly associated with high audit fees due to higher quality demanding from the female CEOs (Huang, Huang, \& Lee, 2014).

\section{Agency theory}

Agency theory is being derived from the financial economics literature and is part of the positivist group of theory of which the approach of study of society that focuses on specifically the scientific evidence, such as experiments and statistics (Adams, 1994). The assumption under the agency theory that everyone will always acts in accordance to own best interest. If the principal and the agent both always finding the opportunity to maximize their own self-interests in this relationship, this may end up that the agent might not always act in the best interests of the principal. As a result, this forces action to be taken against the agent by the principal in order to keep the agent in line with the interest of the principal (Jensen \& Meckling, 1976). AC is one of the corporate governance mechanisms that are expected to provide an oversight role over the entire process of financial reporting to ensure the interest of the shareholders are being protected and prioritized.

Both IAF and AC bond the relationship between principals and agents under the agency theory. Under the agency theory, IAF and AC are recognized as a bonding function borne by the senior managers (agent) of an organization to monitor their behaviour to ensure the interests of the shareholders (principal) of an organization are being served and protected (Ismael \& Roberts, 2018). Most organizations will employ internal auditor and non-executives' directors together with the service of an AC as internal monitoring mechanisms. There is considerable participation by the internal auditors in the external audit. The agency theory suggested that the involvement of internal auditors in the statutory audit activities will reduce the level of monitoring cost of the statutory audit such as the costs of scrutinizing external audit and improve financial reporting and audit quality (Adams, 1994).

\section{Theoretical Framework}

This research study framework consists of four independent variables (IV), one dependent variable (DV), one control variable $(\mathrm{CV})$ and one moderating variable (MV). Characteristics of the AC in association with the audit quality are the main variables of this research study. Firm Size (sales revenue) is the control variable is included in this research model.

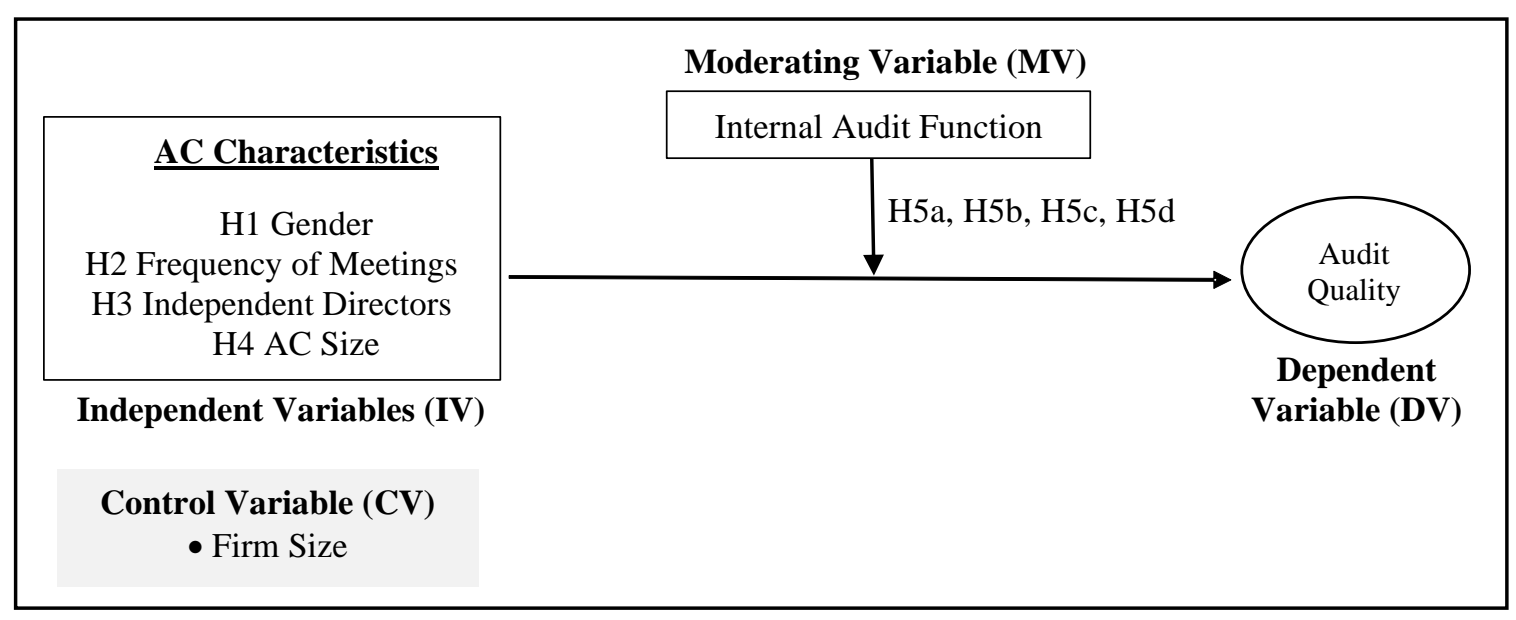

Figure 1. Theoretical Framework 


\section{Hypothesis Development}

\section{AC Characteristic - Gender and Audit Quality}

Most of the previous studies of AC characteristics of gender were focused on earnings management (Peni \& Vähämaa, 2010; Thiruvadi \& Huang, 2011), earnings quality and forecast (Ammer \& Ahmad-Zaluki, 2017; García-Sánchez, Martínez-Ferrero, \& García-Meca, 2017; Nasution \& Jonnergård, 2017), and financial restatements (Oradi \& Izadi, 2019)rather than in the context of audit quality. Monitoring role of female experts has a positive effect on accounting conservatism and earnings quality in banks (García-Sánchez et al., 2017). A reduction in financial restatements is strongly associated with the independent and financial expert of female members in the AC and the likelihood of hiring higher quality auditors can be increased when there is a presence of female members in the AC (Oradi \& Izadi, 2019). However, from one of the study in Sweden showed that the gender of auditor and Chief Financial Officer has no association with earnings quality but interactions between the them will affect earnings quality (Nasution \& Jonnergård, 2017). According to Ammer and Ahmad-Zaluki (2017), AC gender has insignificantly positive relationship with absolute forecast error. This means that female directors in the audit committee could translate into more errors and less accuracy in earnings forecasts (Ammer \& Ahmad-Zaluki, 2017) and a more conservative earnings management strategies are following by female Chief Financial Officers (Peni \& Vähämaa, 2010). According to the agency theory, female AC members (agent) act as a very important mechanism in governance as controlling agent to assist the shareholders of the company to perform duty of the AC, thereby leading in financial reporting quality improvement that will improve overall audit quality from strengthened governance control. Therefore, the study hypothesises that:

\section{H1: The presence of female members in the AC is positively influencing the audit quality}

\section{AC Characteristic - Frequency of AC Meetings and Audit Quality}

$\mathrm{AC}$ is viewed as an important mechanism in improving the quality of statutory audit process. The AC that meet up more frequently and regularly are likely to be aware of the current auditing issues and will be more diligent when performing their duties in accordance to study by Carcello, Hermanson, and Neal (2002). Higher the level of AC meetings implied that the AC members are more active and participative in AC meetings and thus contribute to the better quality of financial reporting (Mbobo \& Umoren, 2016). In order to have an effective AC meetings, AC members are expected to spend significant amount of time to attend the AC meetings (Dhaliwal, Naiker, \& Navissi, 2010). Frequency of quarterly meetings in the AC have a positive relationship with audit quality (Asiriuwa, Aronmwan, Uwuigbe, \& Uwuigbe, 2018). The frequency of AC meetings is associated with the increases of the choosing for better quality and industry specialization audit firm for better audit quality especially on the earnings management (Abbott \& Park, 2000). More frequent meetings of the AC and the increased of the use of IAF will result higher audit fees due to increase of audit testing and higher audit quality (Goodwin-Stewart \& Kent, 2006). Strong AC characteristics such as AC size and frequency of meetings are indicators of audit quality monitoring due to these characteristics are in association with the increased chances of appointing higher quality auditors that will result in providing higher audit quality (Hoitash, Hoitash, $\&$ Bedard, 2009). Therefore, the following hypothesis is tested:

\section{H2: The frequency of AC meetings is positively influencing the audit quality}

\section{AC Characteristics - Independent Directors and Audit Quality}

Independence of $\mathrm{AC}$ members is one of the four attributes for $\mathrm{AC}$ effectiveness that will contribute towards the audit quality (Asiriuwa et al., 2018). Independent directors in the AC is responsible for mitigating the agency problem between the organization and the shareholders of the company by monitoring the overall financial reporting and auditing process. The independent directors are also a mediator between external auditors and management of the organization. Effective AC comprising independent directors, finance experts and frequent AC meetings will undertake more monitoring roles which will result in larger audit scope and higher audit fees (Zaman, Hudaib, \& Haniffa, 2011). In other context than audit quality, the independence of directors' diligence is significant in producing higher quality financial statements that will ended up create real economic value and profitability to the companies (Kapoor \& Goel, 2019; Salehi et al., 2018). It is noted that this will reduce the agency costs by reducing external reporting and to increase the quality of audit. The $\mathrm{AC}$ independence will influence the level of voluntary corporate governance in the scope of disclosure quality. If there is an increase in the quality information provided in the annual reports, this will lead to highly efficient and transparent stock market and also to enhance audit quality in the reporting (Talpur, Lizam, \& Zabri, 2018). Independence of the AC members increases their role in ensuring the quality of reported financial statements and audit quality on earnings quality by Tunisian listed companies and also likely to reduce the time taken to issue the audit report (Zgarni, Hlioui, \& Zehri, 2016). This leads to the following hypothesis:

\section{H3: The independence of directors in the AC is positively influencing the audit quality}




\section{AC Characteristic - AC Size and Audit Quality}

In Malaysia, the listing requirement of Bursa Malaysia and the Malaysian Code on Corporate Governance have recommended that $\mathrm{AC}$ shall comprise of a minimum of three directors. The findings on AC in Nigeria showed a significant positive relationship between AC size and audit quality, i.e. with the AC size of 6 as required by Nigerian legislation will improve the audit quality and the AC size is one of the four attributes for AC effectiveness that will contribute towards the audit quality (Asiriuwa et al., 2018). In agency theory, the AC size will determine the efficiency and effectiveness of the monitoring on the board and the management team that will improve the quality of reporting and audit. AC has significant impact in influencing the level of voluntary corporate governance disclosure that will impact financial reporting and audit quality (Talpur et al., 2018). The size of AC constitutes an important factor for effective performance of the committee. As a result, the AC size must be properly and appropriately stated, the study has recommended the AC size must be large and constitute more members with accounting and finance knowledge will benefits the shareholders (Moses, 2016). Based on the above studies, the following hypothesis is proposed:

\section{H4: The AC size is positively influencing the audit quality}

\section{Moderation role of IAF}

Previous literature showed that AC characteristics and audit quality are having inconsistent results with some mentioning positive relationship exists but the other mentioning negative. Therefore, the second objective is to study the moderation of IAF on the relationship between AC characteristics and audit quality. The moderating variable is to be included in the research study to increase the efficiency of the model and its relationship with AC characteristics and audit quality. The agency theory could explain the presence of internal audit function as monitoring role between the principals, i.e. the shareholders of the organization and the agents, i.e. the management team of the organization. If the relationship between the principals and the agents are utility maximisers, there is always costs incur in monitoring and bonding in order to reduce agency problem (Jensen \& Meckling, 1976). The IAF is important as an internal corporate governance tool and to provide assurance on the effectiveness of the internal control and risk management control systems in order to reduce both internal and external agency costs (Ismael \& Roberts, 2018).

In Malaysia, the AC has the responsibilities towards the IAF for listed companies (SCM, 2017). The AC has the right to approve, remove and assess the work performance of the Head of the Internal Audit, either in-house employed or outsourced. In order to ensure the achievement of the risk-based internal audit and resource plan, the AC must ensure that there is transparency procedures in place and unrestricted access to information and records by the IAF to carry out its roles and responsibilities function effectively. In addition, AC must ensure that the IAF is having sufficient, qualified and competent resources including experienced internal auditors, auditing tools (IIAM, 2017).

On other hand, the existence of AC and IAF reduce the level of earnings management and discretionary accruals, thus improve the financial reporting and audit quality in Jordan (Alzoubi, 2019). In order AC to perform the roles and responsibilities, appropriate level of interactions with IAF is required. On the other hand, IAF's implication towards the reporting and audit quality is largely determined by the level of cooperation with the AC (Tusek, 2015). IAF budget is positively related to the hire of industry-specialist auditors and audit fee. The cost of internal audit is being argued that it will enhance the quality of the internal audit function as the organization's spend on internal audit function will resulting the greater scope of audit work being covered comparing to those organization which is spending less on the internal audit function (AL-Qadasi, Abidin, \& Al-Jaifi, 2019). The internal control quality is positively associated with the AC's involvement in reviewing internal audit field work and effective IAF will provide assurance on internal control quality as well as the financial reporting process that will impact both the reporting and audit quality (Oussii \& Boulila Taktak, 2018).

The IAF is reporting directly to the AC and the AC is reviewing the adequacy and competence of the IAF. In Malaysia, the cost of IAF is disclosed in the annual reports for listed companies. Establishment of IAF is mandatory for all listed companies in Malaysia (Bursa, Updated as at 27/1/2015). One of the research was showing that there is a complementary association between IAF budget and demand for audit quality in the view of hiring specialist auditor (AL-Qadasi et al., 2019). A well-funded IAF has greater ability in monitoring the activities of the company including the board of management behaviour (K.Johl, Kaur Johl, Subramaniam, \& Cooper, 2013). Interaction between independence and competency of the IAF is important as independency and competency of the IAF effect the financial reporting and audit quality (Abbott, Daugherty, Parker, \& Peters, 2016). The sub-hypotheses as follows:

H5a: Internal audit function moderates positively the relationship between AC gender and audit quality

H5b: Internal audit function moderates positively the relationship between AC meetings' frequency and audit quality

H5c: Internal audit function moderates positively the relationship between independence of directors in AC and audit quality

H5d: Internal audit function moderates positively the relationship between AC size and audit quality 


\section{METHODOLOGY}

Quantitative approach is being applied in this research study and utilizing secondary data as main source of information. The data for this study is obtained from the annual reports of selected samples companies from Bursa Malaysia website and the data collected includes both financial variables (cost of IAF, external audit fees etc.) and nonfinancial variables (AC members, frequency of AC meetings etc.). The population of this study consists of companies listed on the Main Market of the stock exchange of Malaysia (Bursa Malaysia) and excludes companies in the insurance and financial sectors due to these sectors are regulated and governed by different rules and regulations. Organization is the unit of analysis for this study. Stratified random sampling techniques are being used in this study of which data was gathered from total sample size of 250 listed companies out of 741 targeted listed companies excluded 52 companies under Insurance and Financial Sectors because financial companies are subject to the different requirement, rules and regulations required by the Bank Negara Malaysia (Devi, Hooper, Uddin, \& Tsamenyi, 2011). The sample size of 250 is determined by using Krejcie and Morgan (1970). The structural equation modelling (SEM) approach is used for the statistical data analysis via SmartPLS.

\section{Measurements of Variables}

The table 1 depicted the measurement of AC characteristics, there are five independent variables, each of dependent, moderating and control variable.

Table 1. Summary of Variable and Measurements

\begin{tabular}{|l|l|l|}
\hline Independent Variables & Label & Measurement \\
\hline Gender in AC & GENRATIO & $\begin{array}{l}\text { The ratio of female directors over total AC } \\
\text { members. It takes the value of 1 if 50\% or more } \\
\text { members are female, 0 otherwise (García-Sánchez } \\
\text { et al., 2017) }\end{array}$ \\
\hline Frequency of AC Meetings & MEFRQ & Number of meetings held per year (Buallay, 2018) \\
\hline Independence members in AC & ACINDP & $\begin{array}{l}\text { Number of independent members in AC. It takes the } \\
\text { value of 1 if all members are independent directors } \\
\text { and 0 otherwise (Alzoubi, 2019) }\end{array}$ \\
\hline AC Size & ACSIZE & $\begin{array}{l}\text { Number of members forming the AC (Asiriuwa et } \\
\text { al., 2018) }\end{array}$ \\
\hline $\begin{array}{l}\text { Dependent Variables - Audit } \\
\text { Quality }\end{array}$ & EXAUFEE \\
\hline $\begin{array}{l}\text { Moderating Variable - Internal } \\
\text { Audit Function }\end{array}$ & IAFCOST & $\begin{array}{l}\text { It measures the actual cost of the internal audit } \\
\text { function. (AL-Qadasi et al., 2019) }\end{array}$ \\
\hline Control Variable - Firm Size & REVM & The sales revenue of the companies. \\
\hline
\end{tabular}

\section{RESULTS}

The data analysis in Smart PLS 3.0 shown that the maximum variable inflation factor (VIF) in this study is 2.019 indicates that there is no harmful correlation exist and this study is not subject to multicollinearity problems. This results in line with Hair Jr, Hult, Ringle, and Sarstedt (2016), an ideal VIF values should be lower than 3. Meanwhile, that variance $\left(\mathrm{R}^{2}\right)$ is 0.048 which is showing weak co-efficient of determination according to Cohen (1988). This represents that $4.8 \%$ of the AC characteristics can explain on audit quality. Further, the results in Table 2 reveal that gender $(\beta=0.167$, $\mathrm{p}<0.1)$, frequency of meetings $(\beta=0.056, p<0.1)$ and independence directors $(\beta=0.07, p<0.1)$ are positively significant with audit quality. Therefore, $\mathrm{H} 1, \mathrm{H} 2$ and $\mathrm{H} 3$ are accepted. The AC size is found not positively associated with audit quality. Hence, $\mathrm{H} 4$ is being rejected. In addition, the model has predictive relevance as the value of $\mathrm{Q}^{2}$ above zero. On other hand, the control variable namely firm size was found does not have significant effect on audit quality.

Table 2. Path Coefficients for Independent Variables

\begin{tabular}{|c|l|c|c|c|c|c|c|}
\hline Hypotheses & \multicolumn{1}{|c|}{ Path } & $\begin{array}{c}\text { Std Beta } \\
(\boldsymbol{\beta})\end{array}$ & SE & t-value & P-value & Decision & $\mathbf{R}^{\mathbf{2}}$ \\
\hline H1 & GENRATION -> AQ & 0.167 & 0.118 & $1.412^{*}$ & 0.079 & Accepted & 0.048 \\
\hline H2 & MEFRQ -> AQ & 0.056 & 0.042 & $1.329^{*}$ & 0.092 & Accepted & \\
\hline H3 & ACINDP -> AQ & 0.070 & 0.052 & $1.356^{*}$ & 0.088 & Accepted & \\
\hline H4 & ACSIZE -> AQ & -0.020 & 0.080 & 0.254 & 0.400 & Rejected & \\
\hline
\end{tabular}

a. Significant level at 1 -tail $* \mathrm{p}<0.1$

b. AQ: Audit Quality, GENRATIO: Gender, MEFRQ: Frequency of meetings, ACINDP: Independence, ACSIZE: Audit committee size

Testing of the Moderating Effect

Table 3. Path Coefficients for Moderating Variables 


\begin{tabular}{|c|l|c|c|c|c|c|}
\hline Hypotheses & \multicolumn{1}{|c|}{ Path } & $\begin{array}{c}\text { Std Beta } \\
(\boldsymbol{\beta})\end{array}$ & $\mathbf{S E}$ & t-value & P-value & Decision \\
\hline H5a & IAF*GENRATION -> AQ $^{*}$ GENR & -0.073 & 0.106 & 0.687 & 0.246 & Rejected \\
\hline H5b & IAF*MEFRQ -> AQ & -0.075 & 0.094 & 0.797 & 0.213 & Rejected \\
\hline H5c & IAF*ACINDP -> AQ $^{*}$ AC & -0.002 & 0.064 & 0.025 & 0.490 & Rejected \\
\hline H5d & IAF*ACSIZE -> AQ & 0.000 & 0.045 & 0.001 & 0.500 & Rejected \\
\hline
\end{tabular}

a. Significant level at 1-tail $* \mathrm{p}<0.1$

b. AQ: Audit Quality, GENRATIO: Gender, MEFRQ: Frequency of meetings, ACINDP: Independence, ACSIZE: Audit committee size, IAF: Internal Audit Function

Surprisingly, the results in Table 3 showed that there was no moderating effect of internal audit function in the relationship between AC characteristics and Audit Quality. Thus, the hypotheses H5a to H5d were rejected. All t-values on the moderating factor results were less than 1.28, this means that the internal audit function did not play the moderating role between AC characteristics and audit quality. However, the comparison of Coefficient of Determination $R^{2}$ without is 0.048 and with internal audit function as Moderating effect depicted that $R^{2}$ of moderating effect is 0.064 implies that $6.4 \%$ variance of business performance is explained by the model. $R^{2}$ changed 0.016 which indicated an increase of $1.6 \%$ invariance.

\section{DISCUSSION}

As expected, the result portrays that companies with more than $50 \%$ of female audit committee (GENRATIO) has a significant positive relationship with audit quality. This is consistent with that findings that female board members will has a positive effect on accounting conservation and earnings quality (García-Sánchez et al., 2017). The presence of women on the board has positive correlation to the financial reporting quality implying that woman play a positive and important role in this area (Alfraih, 2016). This is consistent with the MCCG's direction in enhancing the practice on gender diversity on the boards. Meanwhile, the result also depict that the frequency of AC meetings is positively associated with audit quality. This shows that the number of AC meetings held in a year may aid the audit quality. This is consistent with previous findings that highlighted that AC meeting more frequently and regularly are more likely to be aware of the current auditing status and issues and will be more diligent when performing their duties (Asiriuwa et al., 2018; Dhaliwal et al., 2010; Mbobo \& Umoren, 2016).

In addition, the result revealed that the independence of directors in the AC is a positively significant with the audit quality. This is consistent with study by Asiriuwa et al. (2018). It can explain as independent directors in the AC is responsible for mitigating the agency problem between the organization and the shareholders of the company by monitoring the overall financial reporting and auditing process., When the independent directors are the lead on the AC, they serve a governance role the will improve audit quality, financial report quality and earnings quality (Gao, Omer, \& Shelley, 2019). The benefits of AC independence are consistently achieved only when the AC is comprising of independent directors and this provides support for the SOX requirement in the US of all independent AC requirements (Bronson, Carcello, Hollingsworth, \& Neal, 2009). On the other hand, surprisingly the finding shows that the AC size is not positively associated with the audit quality. This findings is consistent with previous research's findings that AC size has no significant impact on earnings management that will impact the audit and reporting quality (Moses, 2016; Siam, Laili, \& Khairi, 2015). Larger AC's size do not significantly enhance the quality of financial reporting and audit (Soliman \& Ragab, 2014). AC size is insignificant in another context, i.e. in audit delay that will impact audit quality (Oussii \& Taktak, 2018). The AC size has negative but significant relationship with earnings management indicating that AC size is not an important factor to enhance financial reporting and audit quality (Qamhan, Che Haat, Hashim, \& Salleh, 2018).

Unexpectedly, the finding shown that the moderation effect of IAF is insignificant for the relationship between AC characteristics and the audit quality in Malaysia. It may due to the reasons that audit quality by external auditors is not directly affected by the work of IAF. External auditors might rely on the work of internal auditors for control evaluation tasks, however, the external auditors have sole responsibility for the audit opinion and external auditors need to ensure that they have sufficient evidence in forming the audit opinion in the audited financial statements. The AC must make effective use of IAF on risk management, governance and internal control systems. Therefore, the interaction between the variables exist but moderator role of IAF in this area is not significant.

\section{IMPLICATIONS}

The theoretical implications of this study are examining the relationship between AC characteristics, namely gender, frequency of AC meetings, independence members in AC and AC size together with the audit quality among selected listed companies in Malaysia, especially when there is an existence of IAF as moderator. Findings from this study indicating the existence of AC characteristics like gender, frequency of AC meetings and independence members in the $\mathrm{AC}$ are positively associated with the audit quality, this means that existence of AC will improve audit quality. The findings will facilitate researchers and scholars in enhance the understanding of the relationship and role of the AC characteristics particularly the gender, frequency of AC meetings and independence members in the AC played in 
improving overall audit quality by performing their roles and responsibilities for listed companies in Malaysia. Besides that, the strengthen the understanding of agency theory in this research context and fill up the gap in the literature particularly in audit committee, audit quality and internal audit function field of research.

This study also provides practical value of this study on how the IAF using internal audit cost as a proxy of measurement could act as moderator for the relationship between the AC characteristics and the audit quality. Even though the IAF does not have significant moderating effect in the relationship of AC characteristics and audit quality, however, the $\mathrm{AC}$ and the IAF are two important mechanisms in the corporate governance that will improve the financial reporting and audit quality. The companies' stakeholders like professional accountancy body and governments may use the outcomes from this research study to improve existing rules and regulations and code of conducts of its members to improve the quality of their works. For example, currently only listed companies in Malaysia are required to maintain an internal audit function. The professional accountancy body and governments may require listed companies to maintain an in-house internal audit department rather than allowing them to outsource in order to protect the interest of the stakeholders and to provide quality in financial reporting and audit. Additionally, the professional accountancy body and governments may extend the requirement for all companies to maintain the internal audit function.

\section{LIMITATION AND FUTURE STUDIES}

The insight provided by this study showing some limitations that would motivate further research. First, this study is focusing on cross sectional study that using financial results in 2018 for analysis. The financial results for future research may be extended to prior years, i.e. the last five financial years as to ensure larger population is being selected. Secondly, future research may investigate other determinants for audit quality in order to provide a more in-depth explanations on how audit quality will be impacted other than solely focus on the AC characteristics only. Further study may combine $\mathrm{AC}$ characteristics together with other factors such as the external and internal auditors' characteristics. For example, it is worth to study the impact and implications from the recent lawmakers in the UK that has demanded the breakup of Big Four accounting firms for their auditing and consultancy work in delivering higher quality audit services and minimizing the conflict of interest.

\section{CONCLUSION}

High quality in audit and financial reporting are supporting the global financial stability as the users of the financial statements relying on high quality information in managing the affairs of the company by assessing the financial performance and position to make important business decision. The findings from this study indicating that the existence of audit committee like gender, frequency of meetings and independence of directors are positively and significantly associated with audit quality for listed companies in Malaysia. From the findings, it is recommended that organization may increase the female representation, independence directors and frequency of meeting in the AC in order to discuss and follow up any issues and findings in the finance, internal control and audit that will result higher standard of audit quality. This study also found that the moderator role of IAF in the relationship of AC characteristics and audit quality is insignificant. The might due to the internal audit function is reporting to the audit committees and presence of internal audit function helps the audit committee to be aware and knowledgeable about issues on the finance, internal control and audit which will reduce information asymmetry and conflict of interest but internal audit function has played no role as moderator in this regard.

\section{REFERENCES}

Abbott, \& Park, Y. (2000). The effects of audit committee activity and independence on corporate fraud. Managerial Finance, 26(11), 55-68. doi:10.1108/03074350010766990

Abbott, L. J., Daugherty, B., Parker, S., \& Peters, G. F. (2016). Internal Audit Quality and Financial Reporting Quality: The Joint Importance of Independence and Competence. Journal of Accounting Research, 54(1), 3-40. doi:10.1111/1475-679x.12099

Abdullah, S. N., \& Ismail, K. N. I. K. (2016). Women directors, family ownership and earnings management in Malaysia. Asian Review of Accounting, 24(4), 525-550. doi:10.1108/ARA-07-2015-0067

Abdullah, W. N., \& Said, R. (2019). Audit and risk committee in financial crime prevention. Journal of Financial Crime, 26(1), 223234. doi: https://doi.org/10.1108/JFC-11-2017-0116

Adams, M. B. (1994). Agency Theory and the Internal Audit. Managerial Auditing Journal, 9(8), 8-12. Retrieved from https://doi.org/10.1108/02686909410071133

Agyei-Mensah, B. K. (2019). The effect of audit committee effectiveness and audit quality on corporate voluntary disclosure quality. African Journal of Economic and Management Studies, 10(1), 17-31. doi:10.1108/AJEMS-04-2018-0102

Akhtaruddin, M., \& Haron, H. (2010). Board ownership, audit committees' effectiveness and corporate voluntary disclosures. Asian Review of Accounting, 18(1), 68-82. doi:10.1108/13217341011046015

Al-Absy, M. S. M., Ismail, K. N. I. K., \& Chandren, S. (2019). Audit committee chairman characteristics and earnings management: The influence of family chairman. Asia-Pacific Journal of Business Administration, 11(4), 339-370. doi:10.1108/APJBA-102018-0188

Al-Okaily, J., \& Naueihed, S. (2019). Audit committee effectiveness and family firms: impact on performance. Management Decision, 58(6), 1021-1034. doi:https://doi.org/10.1108/MD-04-2018-0422

AL-Qadasi, A. A., Abidin, S., \& Al-Jaifi, H. A. (2019). The puzzle of internal audit function budget toward specialist auditor choice and audit fees: Does family ownership matter? Malaysian evidence". Managerial Auditing Journal, 34(2), $208-243$. 
doi:https://doi.org/10.1108/MAJ-09-2017-1655

Al-sartawi, A., Hamdan, A., Mushtaha, S., \& Ijela, I. (2013). The Effect of Audit Committees on Earnings Management "Empirical study on Manufacturing listed Companies before the International Financial Crisis". An-Najah University Journal for Research - Humanities, 27, 819-846.

Alfraih, M. M. (2016). The effectiveness of board of directors' characteristics in mandatory disclosure compliance. Journal of Financial Regulation and Compliance, 24(2), 154-176. doi:10.1108/JFRC-07-2015-0035

Allegrini, M., \& Greco, G. (2011). Corporate boards, audit committees and voluntary disclosure: Evidence from Italian Listed Companies. Journal of Management \& Governance, 17, 1-30. doi:10.1007/s10997-011-9168-3

Alzoubi, E. S. S. (2019). Audit committee, internal audit function and earnings management: evidence from Jordan. Meditari Accountancy Research, 27(1), 72-90. doi:10.1108/MEDAR-06-2017-0160

Ammer, M. A., \& Ahmad-Zaluki, N. A. (2017). The role of the gender diversity of audit committees in modelling the quality of management earnings forecasts of initial public offers in Malaysia. Gender in Management, 32(6), 420-440. doi:10.1108/GM09-2016-0157

Arena, M., \& Azzone, G. (2009). Identifying Organizational Drivers of Internal Audit Effectiveness. International Journal of Auditing, 13(1), 43-60. doi:10.1111/j.1099-1123.2008.00392.x

Asiriuwa, O., Aronmwan, E. J., Uwuigbe, U., \& Uwuigbe, O. R. (2018). Audit Committee Attributes and Audit Quality: A Benchmark Analysis. Verslas: teorija ir praktika(1), 37-48. doi:https://doi.org/10.3846/btp.2018.05

Baatwah, S. R., Salleh, Z., \& Stewart, J. (2019). Audit committee chair accounting expertise and audit report timeliness: The moderating effect of chair characteristics. Asian Review of Accounting, 27(2), 273-306. doi:10.1108/ARA-12-2017-0190

Bananuka, J., Nkundabanyanga, S. K., Nalukenge, I., \& Kaawaase, T. (2018). Internal audit function, audit committee effectiveness and accountability in the Ugandan statutory corporations. Journal of Financial Reporting and Accounting, 16(1), $138-157$. doi:10.1108/JFRA-07-2016-0062

Bronson, S., Carcello, J., Hollingsworth, C., \& Neal, T. (2009). Are Fully Independent Audit Committees Really Necessary. Journal of Accounting and Public Policy, 28, 265-280. doi:10.1016/j.jaccpubpol.2009.06.001

Buallay, A. (2018). Audit committee characteristics: an empirical investigation of the contribution to intellectual capital efficiency. Measuring Business Excellence, 22(2), 183-200. doi:10.1108/MBE-09-2017-0064

Bursa. (Updated as at 13/3/2019). Main Market: Listing Requirements Chapter 1: Definitions and Interpretation. Bursa Malaysia Retrieved from http://www.bursamalaysia.com/market/regulation/rules/listing-requirements/main-market/listing-requirements

Bursa. (Updated as at 27/1/2015). Main Market: Listing Requirements Chapter 15: Corporate Governance. Bursa Malaysia Retrieved from http://www.bursamalaysia.com/market/regulation/rules/listing-requirements/main-market/listing-requirements

Carcello, J. V., Hermanson, D. R., \& Neal, T. L. (2002). Disclosures in Audit Committee Charters and Reports. Accounting Horizons, 16(4), 291-304. doi:10.2308/acch.2002.16.4.291

Carcello, J. V., Hermanson, R. H., \& McGrath, N. T. (1992). Audit quality attributes: the perceptions of audit partners, preparers and financial statement users. Auditing: A Journal of Practice and Theory, $1(1)$.

Cohen, J. (1988). Statistical power analysis for the behavioral sciences \{Ind cd (2nd ed.). Hillsdale. NJ: Lawrence Erihaum Associates.

Committee on the Financial Aspects of Corporate Governance, \& Cadbury, A. (1992). Report of the Committee on the Financial Aspects of Corporate Governance. Retrieved from London: Gee.: http://cadbury.cjbs.archios.info/report

Davies, R. (2019, 18 April ). Watchdog calls for UK's big four accountancy firms to be split up. Retrieved from https://www.theguardian.com/business/2019/apr/18/watchdog-calls-for-uks-big-four-accountancy-firms-to-be-splitup\#maincontent

Devi, S. S., Hooper, K., Uddin, S., \& Tsamenyi, M. (2011). Accounting in Asia: Emerald Group Publishing.

Dhaliwal, D., Naiker, V., \& Navissi, F. (2010). The Association Between Accruals Quality and the Characteristics of Accounting Experts and Mix of Expertise on Audit Committees. Contemporary Accounting Research, 27(3), 787-827. doi: https://doi.org/10.1111/j.1911-3846.2010.01027.x

Gao, B., Omer, T. C., \& Shelley, M. K. (2019). Do Lead Independent Directors Serving on teh Audit Committee Affect Financial Reporting Quality? SSRN. doi:http://dx.doi.org/10.2139/ssrn.3290898

García-Sánchez, I.-M., Martínez-Ferrero, J., \& García-Meca, E. (2017). Gender diversity, financial expertise and its effects on accounting quality. Management Decision, 55(2), 347-382. doi:https://doi.org/10.1108/MD-02-2016-0090

Goodwin-Stewart, J., \& Kent, P. (2006). Relation between external audit fees, audit committee characteristics and internal audit. Accounting \& Finance, 46(3), 387-404. doi:10.1111/j.1467-629X.2006.00174.x

Hair Jr, J. F., Hult, G. T. M., Ringle, C., \& Sarstedt, M. (2016). A primer on partial least squares structural equation modeling (PLSSEM): Sage publications.

Hamid, K. C. A., Othman, S., \& Rahim, M. A. (2015). Independence and Financial Knowledge on Audit Committee with Noncompliance of Financial Disclosure: A Study of Listed Companies Issued with Public Reprimand in Malaysia. Procedia - Social and Behavioral Sciences, 172, 754-761. doi:https://doi.org/10.1016/j.sbspro.2015.01.429

Hoitash, U., Hoitash, R., \& Bedard, J. C. (2009). Corporate Governance and Internal Control over Financial Reporting: A Comparison of Regulatory Regimes. The Accounting Review, 84(3), 839-867. doi:10.2308/accr.2009.84.3.839

Huang, T.-C., Huang, H.-W., \& Lee, C.-C. (2014). Corporate executive's gender and audit fees. Managerial Auditing Journal, 29(6), 527-547. doi:https://doi.org/10.1108/MAJ-03-2013-0837

IAASB. (2014). A Framework For Audit Quality: Key Elements That Create An Environment For Audit Quality. Retrieved from https://www.ifac.org/system/files/publications/files/A-Framework-for-Audit-Quality-Key-Elements-that-Create-anEnvironment-for-Audit-Quality-2.pdf

IIAM. (2017). Guidance for an effective internal audit function. The Institute of Internal Auditors Malaysia Retrieved from https://www.iiam.com.my/wp-content/uploads/2017/10/GIAF.pdf

Ismael, H. R., \& Roberts, C. (2018). Factors affecting the voluntary use of internal audit: evidence from the UK. Managerial Auditing Journal, 33(3), 288-317. doi:10.1108/MAJ-08-2016-1425

Jensen, M. C., \& Meckling, W. H. (1976). Theory of the firm: Managerial behavior, agency costs and ownership structure. Journal of Financial Economics, 3(4), 305-360. doi:https://doi.org/10.1016/0304-405X(76)90026-X

K.Johl, S., Kaur Johl, S., Subramaniam, N., \& Cooper, B. (2013). Internal audit function, board quality and financial reporting quality: evidence from Malaysia. Managerial Auditing Journal, 28(9), 780-814. doi:https://doi.org/10.1108/MAJ-06-2013-0886 
Kapoor, N., \& Goel, S. (2019). Do diligent independent directors restrain earnings management practices? Indian lessons for the global world. Asian Journal of Accounting Research, 4(1), 52-69. doi:10.1108/AJAR-10-2018-0039

Krejcie, R. V., \& Morgan, D. W. (1970). Determining sample size for research activities. Educational and psychological measurement, 30(3), 607-610.

Krishnan, J. (2005). Audit Committee Quality and Internal Control: An Empirical Analysis. The Accounting Review, 80(2), 649-675. doi:10.2308/accr.2005.80.2.649

Kusumawati, A., \& Syamsuddin, S. (2018). The effect of auditor quality to professional skepticsm and its relationship to audit quality. International Journal of Law and Management, 60(4), 998-1008. doi:10.1108/IJLMA-03-2017-0062

Lee, L. (2019, January 26). Malaysia probing audit firms' conduct in 1MDB scandal. Reuter. Retrieved from https://www.reuters.com/article/us-malaysia-politics-1mdb-auditors/malaysia-probing-audit-firms-conduct-in-1mdb-scandalidUSKCN1PK079

Leung, E. Y. (2013). Can internal auditors be used to provide direct assistance to the external auditor for purposes of audit? Using the work of internal auditors. Retrieved from https://www.accaglobal.com/gb/en/student/exam-support-resources/fundamentalsexams-study-resources/f8/technical-articles/internal-auditors.html

Martinov-Bennie, N., Soh, D. S. B., \& Tweedie, D. (2015). An investigation into the roles, characteristics, expectations and evaluation practices of audit committees. Managerial Auditing Journal, 30(8/9), 727-755. doi:10.1108/MAJ-05-2015-1186

Mbobo, M. E., \& Umoren, A. O. (2016). The influence of audit committee attributes on the quality fo financial reporting. Inernational Journal of Economics, Commerce and Management, IV(7). Retrieved from http://ijecm.co.uk/wpcontent/uploads/2016/07/478.pdf

Moses, T. (2016). The impact of audit committeee size on the quality of financial reporting in quoted Nigerian Banks. International Journal of Advanced Academic Research 2(5).

Nasution, D., \& Jonnergård, K. (2017). Do auditor and CFO gender matter to earnings quality? Evidence from Sweden. Gender in Management, 32(5), 330-351. doi:https://doi.org/10.1108/GM-06-2016-0125

Oradi, J., \& Izadi, J. (2019). Audit committee gender diversity and financial reporting: evidence from restatements. Managerial Auditing Journal, 35(1), 67-92. doi:10.1108/MAJ-10-2018-2048

Oussii, A. A., \& Boulila Taktak, N. (2018). The impact of internal audit function characteristics on internal control quality. Managerial Auditing Journal, 33(5), 450-469. doi:10.1108/MAJ-06-2017-1579

Oussii, A. A., \& Taktak, B. N. (2018). Audit committee effectiveness and financial reporting timeliness. African Journal of Economic and Management Studies, 9(1), 34-55. doi:10.1108/AJEMS-11-2016-0163

Peni, E., \& Vähämaa, S. (2010). Female executives and earnings management. Managerial Finance, 36(7), 629-645. doi:10.1108/03074351011050343

Qamhan, M. A., Che Haat, M. H., Hashim, H. A., \& Salleh, Z. (2018). Earnings management: do attendance and changes of audit committee members matter? Managerial Auditing Journal, 33(8/9), 760-778. doi:https://doi.org/10.1108/MAJ-05-2017-1560

Safari, M. (2017). Board and audit committee effectiveness in the post-ASX Corporate Governance Principles and Recommendations era. Managerial Finance, 43(10), 1137-1151. doi:10.1108/MF-07-2015-0185

Salehi, M., Moradi, M., \& Paiydarmanesh, N. (2017). The Effect of Corporate Governance and Audit Quality on Disclosure Quality: Evidence from Tehran Stock Exchange. Periodica Polytechnica Social and Management Sciences, 25(1), 32-48. doi:10.3311/PPso.8354

Salehi, M., Tahervafaei, M., \& Tarighi, H. (2018). The effect of characteristics of audit committee and board on corporate profitability in Iran. Journal of Economic and Administrative Sciences, 34(1), 71-88. doi:10.1108/JEAS-04-2017-0017

SCM. (2017). Malaysian Code on Corporate Governanace. Securities Commission Malaysia Retrieved from www.sc.com.my

Siam, Y. A., Laili, N. H., \& Khairi, K. F. (2015). The Relationship between Audit Committee Characteristics and Earnings Management among Jordanian Listed Companies: Proposing Conceptual Framework. Research Journal of Finance and Accounting, 6(18), 20-45.

Soliman, M. M., \& Ragab, A. A. (2014). Audit Committee Effectiveness, Audit Quality and Earnings Management: An Empirical Study of the Listed Companies in Egypt. Research Journal of Finance and Accounting, 5(2), 1-29.

Sprouse, W. (2019, June 5 ). PwC to restructure UK audit practice. CFO Magazine. Retrieved from https://www.cfo.com/strategy/2019/06/pwc-to-restructure-u-k-audit-practice/

Talpur, S., Lizam, M., \& Zabri, S. M. (2018). Do audit committee structure increases influence the level of voluntary corporate governance disclosures? Property Management, 36(5), 544-561. doi:https://doi.org/10.1108/PM-07-2017-0042

Thiruvadi, S., \& Huang, H. W. (2011). Audit committee gender differences and earnings management. Gender in Management: An International Journal, 26(7), 483-498. doi:10.1108/17542411111175469

Tusek, B. (2015). The influence of the audit committee on the internal audit operations in the system of corporate governance - evidence from Croatia. Research-Ekonomska Istraživanja, 28(1), 187-203. doi:10.1080/1331677X.2015.1028245

Zaman, M., Hudaib, M., \& Haniffa, R. (2011). Corporate governance quality, audit fees and non - audit services fees. Journal of Business Finance \& Accounting, 38(1-2), 165-197.

Zgarni, I., Hlioui, K., \& Zehri, F. (2016). Effective audit committee, audit quality and earnings management. Journal of Accounting in Emerging Economies, 6(2), 138-155. doi:10.1108/JAEE-09-2013-0048

accese, J. B., Buckley, T. A., Tierney, R. T., Arbogast, K. B., Rose, W. C., Glutting, J. J., \& Kaminski, T. W. (2018). Head and neck size and neck strength predict linear and rotational acceleration during purposeful soccer heading. Sports Biomechanics, 17(4), 462-476. https://doi.org/10.1080/14763141.2017.1360385

Huang, X., Sun, J., \& Sun, J. (2018). A car-following model considering asymmetric driving behavior based on long short-term memory neural networks. Transportation Research Part C: Emerging Technologies, 95(February), 346-362. https://doi.org/10.1016/j.trc.2018.07.022

James, S. L., Abate, D., Abate, K. H., Abay, S. M., Abbafati, C., Abbasi, N., Abbastabar, H., Abd-Allah, F., Abdela, J., Abdelalim, A., Abdollahpour, I., Abdulkader, R. S., Abebe, Z., Abera, S. F., Abil, O. Z., Abraha, H. N., Abu-Raddad, L. J., Abu-Rmeileh, N. M. E., Accrombessi, M. M. K., ... Murray, C. J. L. (2018). Global, regional, and national incidence, prevalence, and years lived with disability for 354 diseases and injuries for 195 countries and territories, 1990-2017: a systematic analysis for the Global Burden of Disease Study 2017. The Lancet, 392(10159), 1789-1858. https://doi.org/10.1016/S0140-6736(18)32279-7

Tan, H., Qin, L., Jiang, Z., Wu, Y., \& Ran, B. (2018). A hybrid deep learning based traffic flow prediction method and its understanding. 
Transportation Research Part C: Emerging Technologies, 90(January), 166-180. https://doi.org/10.1016/j.trc.2018.03.001

Taylor, K., Post, A., Hoshizaki, T. B., \& Gilchrist, M. D. (2019). The effect of a novel impact management strategy on maximum principal strain for reconstructions of American football concussive events. Proceedings of the Institution of Mechanical Engineers, Part P: Journal of Sports Engineering and Technology, 233(4), 503-513. https://doi.org/10.1177/1754337119857434

\section{ACKNOWLEDGEMENT}

The authors would like to thank Universiti Sains Malaysia for funding this work under the Incentive-Bridging Grant Scheme 304/PPAMC/6316433.

\section{AUTHORS' BIOGRAPHY}

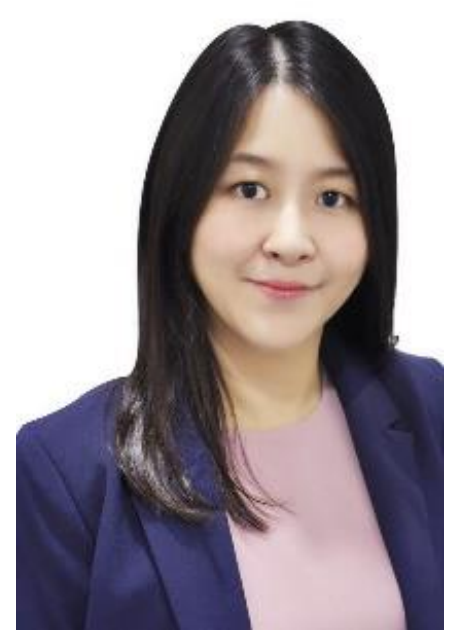

Josephine Kuan is a Business Development Manager at Grain \& Protein Greater Asia, AGCO Corporation. She earned her Bsc (Hons.) in Applied Accounting with Oxford Brookes University, UK and recently graduated her MBA with University of Science, Malaysia. She is a fellow member of The Association of Chartered Certified Accountants, member of the Malaysian Institute of Accountants and the ASEAN Chartered Professional Accountant.

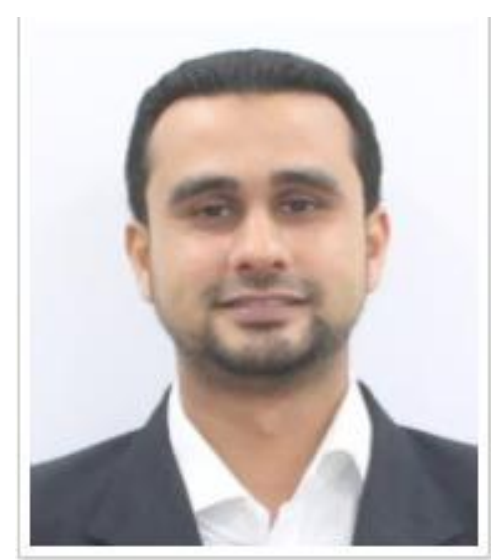

Anwar Allah Pitchay is a senior lecturer at School of Management, Universiti Sains Malaysia. He joined the university in 2015. His research interests are in the areas of Islamic Banking and Finance and governance. He has published more 40 articles in indexed journals and, have grants and won awards. 


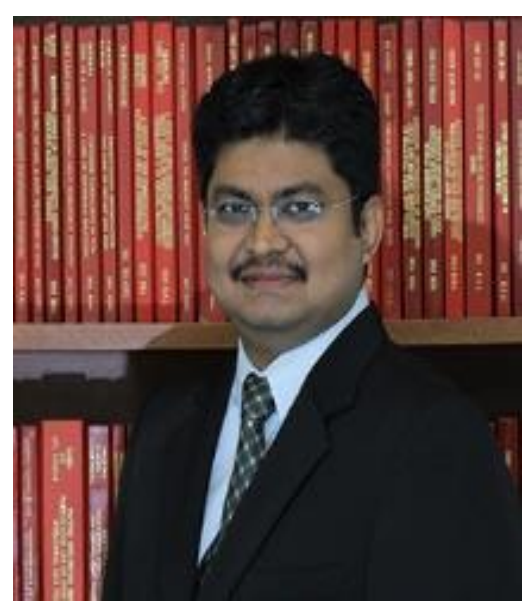

Yuvaraj Ganesan is a senior lecturer at Graduate School of Business, Universiti Sains Malaysia. His research interests are Auditing, Service Quality, Corporate Governance, CSR, SMEs. He has published articles in various indexed and refereed journals. He is a member of Malaysian Institute of Accountants (MIA) and Institute of Internal Audit, Malaysia (IIAM).

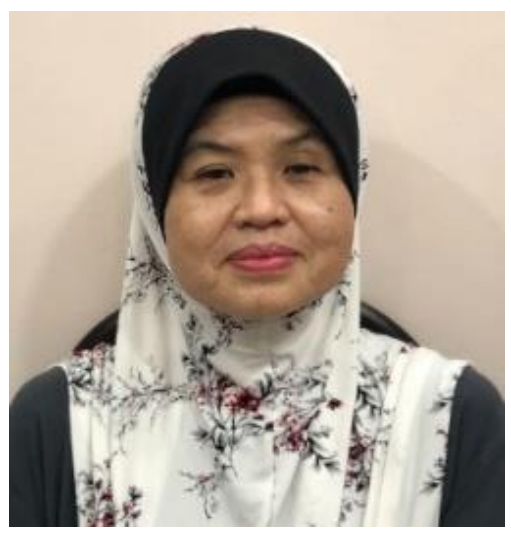

Hasnah Haron is a Senior Academic Fellow at the Faculty of Economics and Mualamat, Universiti Sains Islam Malaysia. She was conferred a PhD from the University of Hull in 1996 with a specialisation in Auditing. She was formerly attached to Universiti Teknologi Mara, Universiti Sains Malaysia and Universiti Malaysia Pahang.

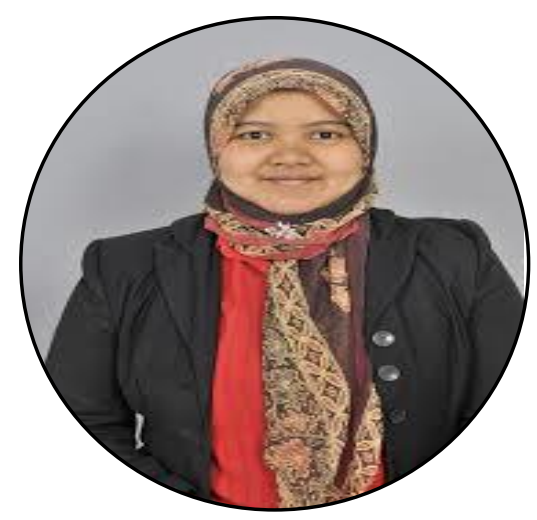

Ratih Hendayani is a Lecture at the School of Economics and Business, Telkom University. She graduated PhD from Universiti Sains Malaysia. Her research topic is about Operational Quality Management and Supply Chain Management. She has published several research articles in international journals and proceedings. She is an editor for the national accredited journal "Jurnal Manajemen Indonesia" and had been a reviewer for IGI publisher. 